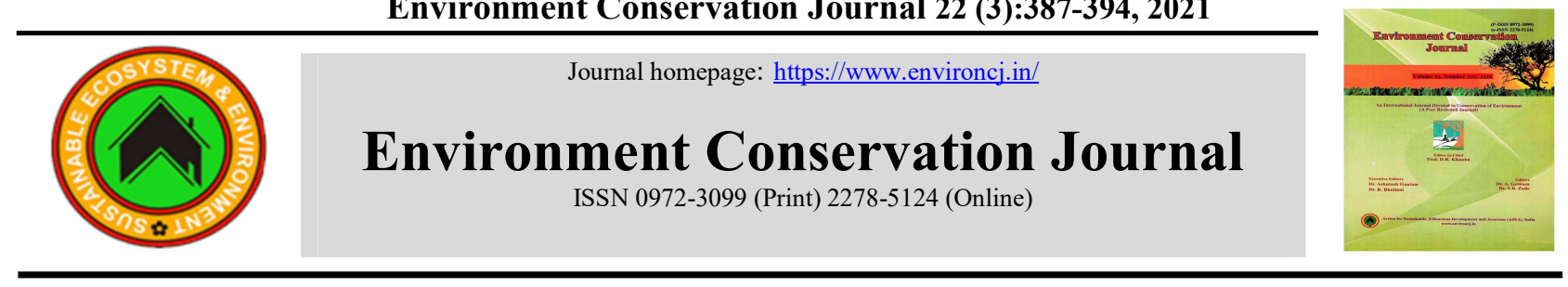

\title{
Assessment of groundwater quality of two selected villages of Nawada district of Bihar using water quality index
}

\author{
Mukesh Ruhela \\ Department of Environmental Engineering, Swami Vivekanand Subharti University, Meerut (UP), India \\ Vikas Kumar Singh \\ Department of Environmental Engineering, Swami Vivekanand Subharti University, Meerut (UP), India \\ Faheem Ahamad $\times$ \\ Keral Verma Subharti College of Sciences, Swami Vivekanand Subharti University Meerut (UP), India
}

\begin{tabular}{|c|c|}
\hline ARTICLE INFO & ABSTRACT \\
\hline $\begin{array}{l}\text { Received : } 02 \text { August } 2021 \\
\text { Revised : } 31 \text { August } 2021 \\
\text { Accepted : } 14 \text { September } 2021 \\
\text { Available online: } 19 \text { December } 2021 \\
\text { Key Words: } \\
\text { Fluoride } \\
\text { Total dissolved solids } \\
\text { Fluoride removal centre (FRC) } \\
\text { water quality index (WQI) }\end{array}$ & $\begin{array}{l}\text { Unplanned discarding of industrial effluent, sewage, domestic and industrial } \\
\text { solid waste, unwise use of insecticides, herbicides, pesticides, and fertilizer in } \\
\text { agriculture are the major causes of groundwater quality reduction. In the } \\
\text { present paper groundwater quality of the two selected village of Rajauli } \\
\text { subdivision of Nawada district of Bihar was assessed using water quality index } \\
\text { (WQI). The samples were figured out for the parameters such as temperature, } \\
\text { pH, electrical conductivity (EC), total dissolved solids (TDS), alkalinity, } \\
\text { dissolved oxygen (DO), total hardness (TH), chloride, calcium (Ca), magnesium } \\
\text { (Mg), biochemical oxygen demand (BOD), and fluoride. All the parameters } \\
\text { were found below the standard limits of Bureau of Indian Standard (BIS, 2012) } \\
\text { except total hardness (328.1mg/l to } 346.6 \mathrm{mg} / \mathrm{l}) \text {, calcium (105.3mg/l to } 122.6 \mathrm{mg} / \mathrm{l}) \text {, } \\
\text { magnesium ( } 46.1 \mathrm{mg} / \mathrm{l} \text { to } 55.7 \mathrm{mg} / \mathrm{I}) \text { and fluoride }(4.8 \text { to } 4.9 \mathrm{mg} / \mathrm{l}) \text {. Fluoride was } \\
\text { observed more than } 3 \text { times than the standard permissible limit (1.5mg/l). } \\
\text { Water quality index (WQI) was also applied on the obtained data to make it } \\
\text { easy to understand. Based on WQI (including the fluoride), all the four sites fall } \\
\text { in unfit for drinking category (250.79, } 258.78,281.78,247.30) \text { and in poor to } \\
\text { very poor category ( } 80.23,88.19,88.59,64.60) \text { excluding the fluoride from WQI } \\
\text { calculation. Both the values of WQI shows that fluoride alone is not responsible } \\
\text { for the degraded quality of water but other high concentration of salts is also } \\
\text { responsible. }\end{array}$ \\
\hline
\end{tabular}

\section{Introduction}

Water alone makes approximately $70 \%$ of the Yuan et al., 2020). A large quantity of water human body weight and $97 \%$ of the plant weight. Groundwater is the primary source of potable water and therefore an important part of water systems (Samal et al., 2020; Li et al., 2021). Different types of ions are present in water depending on the geology of the area and activities upon the ground (Todd, 1980) but major focus is paid on the ions of extremes concentrations (high or low) which disturb the chemistry of the water causing the water harmful to the health of living beings and unsuitable for many other purposes (Brindha and Elango, 2011). Population explosion, industrial revolution and green revolution are the major causes of water contamination (Ahmed et al., 2019; supplied to the individuals returned as wastewater and discharged directly or in untreated form and partially treated form on the open ground or in surface water bodies making them polluted. Similarly wastewater discharge from industries also contains pollutants especially heavy metals which make the water bodies polluted. Agricultural runoff contains remains of fertilizers, pesticides, herbicides and weedicides which are released directly in the surface water bodies making them polluted. These pollutants get absorbed in the sediments and then reached the underground water level due to percolation. In that way all the sources of potable water becomes polluted causing different 
problems to the user. Groundwater pollution increases the cost of water treatment along with the problem of water shortage (Chen et al., 2021). Now the quantity and quality of groundwater are two important aspects to be addressed simultaneously (Yousefi et al., 2018; Hua et al., 2020).

Different heavy metal present in water causes different diseases (such as mercury causes minimata, arsenic causes black foot disease, lead causes cancer, cadmium causes itai-itai). Similarly fluoride causes fluorosis, dental mottle and dental carries. Although fluoride can be found in air, water and soil but water may be considered as major contributor of fluorosis (Gupta et al., 2005). As per World Health Organization (WHO), $1.50 \mathrm{mg} / \mathrm{l}$ is permissible for drinking water and as per Bureau of Indian Standards (BIS, 2012). However, at $1.20 \mathrm{mg} / 1$ of fluoride in water fluorosis and at $0.60 \mathrm{mg} / 1$ of fluoride dental caries was observed in India (ISI, 1983). Paleoclimatic, geogenic (evaporation and infiltration of stagnant water) and anthropogenic (industrial discharge, waste of brick industry, fertilizers, and leakage of aquifer etc.), porosity and $\mathrm{pH}$ of rocks and soils, depth of well, age of groundwater, residence time, low calcium and high sodium bicarbonate and carbonate value are some of the factors which controls the fluoride in water (Kundu et al., 2001; Smedley et al., 2002; Edmunds and Smedley, 2005; Kim and Jeong, 2005; Vithanage and Bhattacharya, 2015). Due to water soluble nature, fluoride is widely found in earth crust as well as below it. Along with industrial discharges (such as discharge of aluminum extraction industry), tea, rock-salt and food grains like sorghum, Ragi, Bajra etc. are the other sources of fluoride (Singh et al., 2009). The fluoride which reached to gastrointestinal tract through water, food, medicine and cosmetics get completely absorbed and its distribution throughout the body take place rapidly. Fluorine (highly electronegative element) gets attracted by calcium ions (positively charged) present in bones and teeth which results in flake of teeth and later skeletal fluorosis (Frazao et al., 2011). Fluoride is eliminated via urine, sweat and faeces in little amount and gets bounded in tissues in large amount (Kumar and Kumar, 2015).

Water quality index (WQI) helps in understanding quality of water and therefore has been applied for the quality estimation of the water all over the world form the last few decades (Verma et al., 2018; Bhutiani et al., 2018; Adimallaa and Qian, 2019; Vaiphei et al., 2020; Bhutiani et al., 2021). Water quality is means of reflecting the quality of water in a single value (Sener et al., 2017; Tyagi et al., 2020). Various water quality calculation methods have been developed by several researchers and also by several countries.

Therefore the present study was carried out to investigate the groundwater quality of the two selected village of Rajauli subdivision Nawada district of Bihar using Water quality index (WQI).

\section{Material and Methods Study area}

Nawada district is situated at $24.88^{\circ} \mathrm{N} 85.53^{\circ} \mathrm{E}$ at an elevation of 80 meters $(260 \mathrm{ft}$ ) above sea level with an area of 2,492 $\mathrm{km}^{2}$ (962 sq mi) in the southern part of Bihar and the administrative headquarters is Nawada town. The groundwater depth varies from 2 to 5 meter in post monsoon season and 5 to 10 meter in pre monsoon season. Clay loam type soil is found in most of the parts of Rajauli subdivision. Rainfall in the district is $1037 \mathrm{~mm}$ (CGWB, Groundwater information booklet, 2013).

\section{Sampling and analysis}

The samples from the four selected sampling point of selected villages (Kachahariyadih and Muslim Tola, figure 1) were collected in polythene containers of 2-3 liter capacity in the morning hours (7:00AM to 10:00AM) for five months (from November 2020 to March 2021). The selected villages were divided into two quota (I and II) and then 5 samples were collected from each quota and mixed to prepare the representative samples of that particular quota. In this way samples were collected from all the four sampling quota of both the selected villages. Temperature, Colour, $\mathrm{pH}$ and electrical conductivity (EC) were analyzed at sampling location and remaining sample were transported to the laboratory to analyze the total hardness (TH), total dissolved solids (TDS), calcium $(\mathrm{Ca})$, magnesium $(\mathrm{Mg})$, dissolved oxygen (DO), biochemical oxygen demand (BOD), chloride, alkalinity, and fluoride. All the selected physicochemical parameters were analyzed following the standard methods prescribed in APHA, (2012), and Khanna and Bhutiani (2008). 


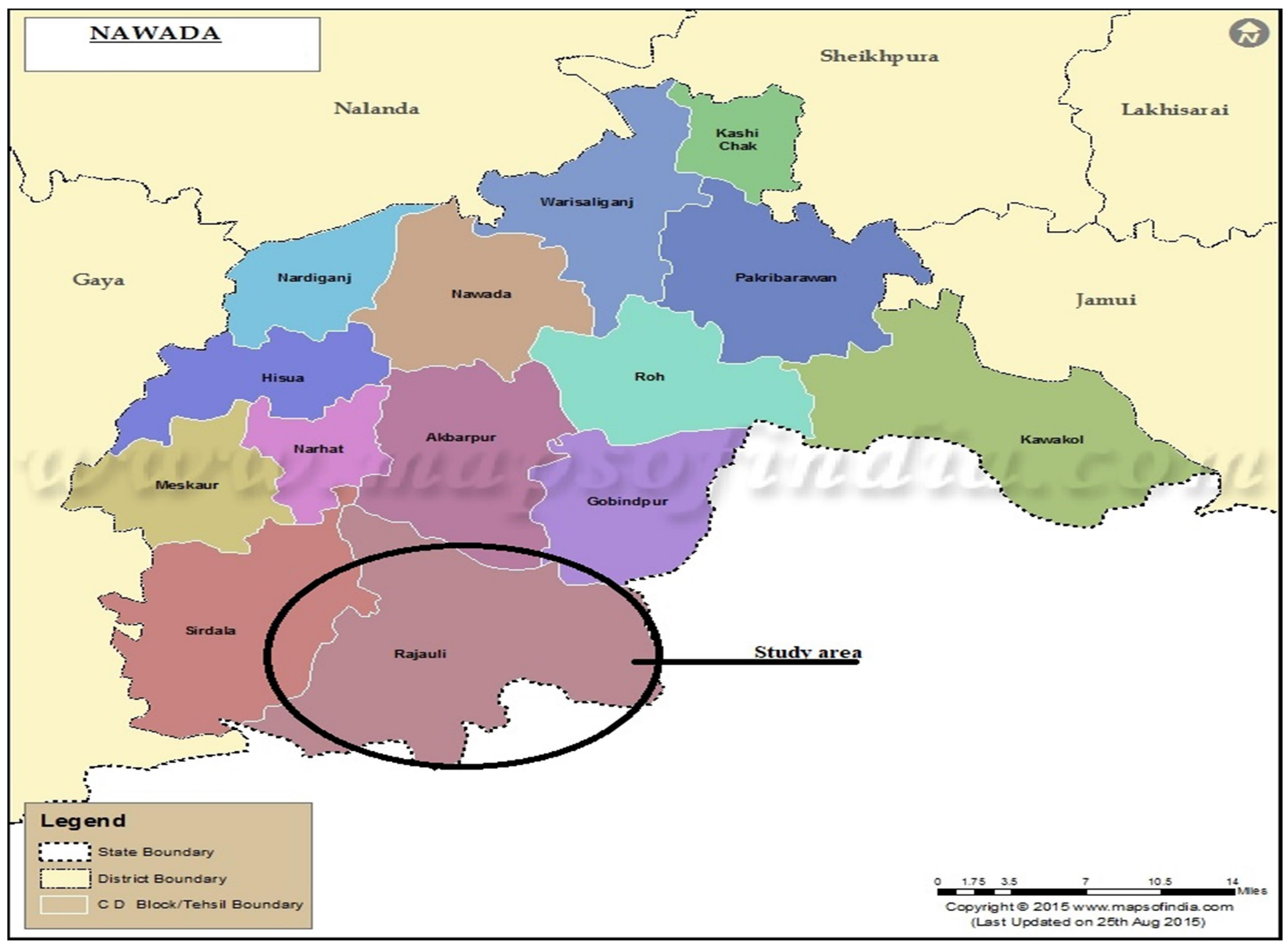

Figure 1: Showing the Rajauli sub-division of Nawada District selected for the present study

\section{Water Quality Index (WQI)}

Water Quality Index (WQI) is a very useful and efficient method, which can provide a simple indicator of water quality and is based on several important parameters. In the present study, the WQI was calculated using the weighted arithmetic index method of Cude (2001) and Brown et al. (1970). In this model, the components with different water quality are multiplied by a weighting factor and then collected using a simple arithmetic mean. To assess water quality first, a Quality Rating Scale (Qn) was calculated for each parameter and then WQI was calculated using the given equation:-

Where,

$$
W Q I=\frac{\sum Q n W n}{\sum W n}
$$

Qn $=$ Quality rating

$\mathrm{Wn}=$ Relative (unit) weight

WQI scale and water quality categorization is given in Table 1.
Table 1: Water Quality Index (WQI) and its status according to Chaterjee and Raziuddin (2002)

\begin{tabular}{|l|l|}
\hline $\begin{array}{l}\text { Water quality Index } \\
\text { Level }\end{array}$ & Water Quality Status \\
\hline $0-25$ & Excellent water quality \\
\hline $26-50$ & Good water quality \\
\hline $51-75$ & Poor water quality \\
\hline $76-100$ & Very poor water quality \\
\hline$>100$ & Unsuitable for drinking \\
\hline
\end{tabular}

\section{Results and Discussion}

Average results of groundwater quality of the selected villages are given in table 2 while the correlation was given in table 3 and the observed values $(\mathrm{OV})$, subindex $(\mathrm{Si})$ and water quality index (WQI) are given in table 4 and figure 2.

Temperature is an important factor for the development of organism (Ram et al., 2007) as it controls many bio-chemical reactions. In the winter season, the reduced water temperature may be due 
to the shorter photoperiod and a fall in the atmosphere. With the elevated atmosphere temperature, the water temperature increases. Temperature was found minimum at site 4 $(25.6 \pm 0.37)$ and maximum was found at site 1 (25.9 \pm 0.35$)$. Results of temperature were in accordance with by Gouri and Choudhary (2017). A very strong positive correlation of temperature was observed with turbidity $(+0.94)$ and hardness $(+0.92)$, and very strong negative correlation with alkalinity (-0.93) and chloride (-0.98) and moderate negative correlation with TDS $(-0.56)$ and EC (0.56). $\mathrm{pH}$ is one of the important parameter to determine the suitability of groundwater for drinking purpose (Salunke et al., 2014). pH was found minimum at site $4(7.3 \pm 0.05)$ and maximum was found at site 2 and 3 ( $7.5 \pm 0.19)$. A very strong positive correlation of $\mathrm{pH}$ was observed with calcium $(+0.98)$ and BOD $(+0.90)$ while strong positive correlation with hardness $(+0.76)$ and strong negative correlation with alkalinity $(-0.67)$. Moderate negative correlation of $\mathrm{pH}$ was observed with TDS (-0.59), EC (-0.59), DO (-0.53) and chloride $(-0.56)$ while moderate positive correlation with fluoride $(+0.54) . \mathrm{pH}$ was found within the standard limit o BIS (6.5 to 8.5). More or less similar concentration was observed by Gouri and Choudhary (2017). Electrical Conductivity (EC) is the capacity of water and wastewater to transmit the current from one point to another and is also an indicator of the amount of salt present in water (Aguado et al., 2006). EC was found minimum at site $3(719.7 \mathrm{~ms} / \mathrm{cm} \pm 20.44)$ and maximum was found at site $4(769.4 \mathrm{~ms} / \mathrm{cm} \pm 13.78)$. A very strong negative correlation of EC was observed with fluoride (-0.92) while strong negative correlation with hardness $(-0.75)$ and magnesium $(-0.67)$.

Table 2: Showing the physicochemical parameters at all the study sites

\begin{tabular}{|c|c|c|c|c|c|}
\hline Parameters & BIS Limit & $\begin{array}{l}\text { Site } 1 \\
\text { (Kachahariyadih } \\
\text {-A1) }\end{array}$ & $\begin{array}{l}\text { Site } 2 \\
\text { (Kachahariyadih } \\
\text {-A2) }\end{array}$ & $\begin{array}{l}\text { Site } 3 \\
\text { (Mushlim } \\
\text { Tola-A1) }\end{array}$ & $\begin{array}{l}\text { Site } 4 \\
\text { (Mushlim } \\
\text { Tola-A2) }\end{array}$ \\
\hline $\begin{array}{l}\text { Temperature } \\
\left({ }^{0} \mathrm{C}\right)\end{array}$ & & $\begin{array}{l}(25.6-26.4)^{*} \\
25.9 \pm 0.35\end{array}$ & $\begin{array}{l}(25.3-26.1)^{*} \\
25.7 \pm 0.39\end{array}$ & $\begin{array}{l}(25.6-26.1)^{*} \\
25.8 \pm 0.19\end{array}$ & $\begin{array}{l}(25.3-26.1)^{*} \\
25.6 \pm 0.37\end{array}$ \\
\hline $\mathrm{pH}$ & $6.5-8.5$ & $\begin{array}{l}(7.3-7.7)^{*} \\
7.4 \pm 0.17\end{array}$ & $\begin{array}{l}(7.3-7.7)^{*} \\
7.5 \pm 0.19\end{array}$ & $\begin{array}{l}(7.3-7.6)^{*} \\
7.5 \pm 0.13\end{array}$ & $\begin{array}{l}(7.2-7.3)^{*} \\
7.3 \pm 0.05\end{array}$ \\
\hline $\begin{array}{l}\text { EC } \\
(\mu \mathrm{s} / \mathrm{cm})\end{array}$ & & $\begin{array}{l}(737.9-772.7)^{*} \\
751.8 \pm 13.27\end{array}$ & $\begin{array}{l}(734.8-781.8) * \\
759.7 \pm 17.88\end{array}$ & $\begin{array}{l}(690.9-740.9) * \\
719.7 \pm 20.44\end{array}$ & $\begin{array}{l}(754.5-786.4)^{*} \\
769.4 \pm 13.78\end{array}$ \\
\hline $\begin{array}{l}\text { TDS } \\
(\mathrm{mg} / \mathrm{l})\end{array}$ & 500 & $\begin{array}{l}(487-510)^{*} \\
496.2 \pm 8.76\end{array}$ & $\begin{array}{l}(485-516)^{*} \\
501.4 \pm 11.80\end{array}$ & $\begin{array}{l}(456-489)^{*} \\
475.0 \pm 13.49\end{array}$ & $\begin{array}{l}(498-519)^{*} \\
507.8 \pm 9.09\end{array}$ \\
\hline $\begin{array}{l}\text { Turbidity } \\
\text { (NTU) }\end{array}$ & & $\begin{array}{l}(3.2-4.3)^{*} \\
3.6 \pm 0.60\end{array}$ & $\begin{array}{l}(1.9-2.8)^{*} \\
2.2 \pm 0.34\end{array}$ & $\begin{array}{l}(2.7-3.1)^{*} \\
2.9 \pm 0.20\end{array}$ & $\begin{array}{l}(1.9-2.8)^{*} \\
2.2 \pm 0.37\end{array}$ \\
\hline $\begin{array}{l}\text { TH } \\
(\mathrm{mg} / \mathrm{l})\end{array}$ & 300 & $\begin{array}{l}(333-350)^{*} \\
346.6 \pm 7.99\end{array}$ & $\begin{array}{l}(325-354)^{*} \\
337.8 \pm 11.56\end{array}$ & $\begin{array}{l}(333-354)^{*} \\
346.6 \pm 7.99\end{array}$ & $\begin{array}{l}(315-331)^{*} \\
322.4 \pm 5.98\end{array}$ \\
\hline $\begin{array}{l}\text { Calcium } \\
(\mathrm{mg} / \mathrm{l})\end{array}$ & 75 & $\begin{array}{l}(109-123)^{*} \\
118.4 \pm 6.54\end{array}$ & $\begin{array}{l}(114-135)^{*} \\
122.6 \pm 8.56\end{array}$ & $\begin{array}{l}(115-126)^{*} \\
120.6 \pm 3.91\end{array}$ & $\begin{array}{l}(97-112)^{*} \\
105.8 \pm 6.46\end{array}$ \\
\hline $\begin{array}{l}\text { Magnesium } \\
(\mathrm{mg} / \mathrm{l})\end{array}$ & 30 & $\begin{array}{l}(53.4-55.4)^{*} \\
55.7 \pm 2.41\end{array}$ & $\begin{array}{l}(48.1-58.3)^{*} \\
52.5 \pm 4.19\end{array}$ & $\begin{array}{l}(53.2-55.9)^{*} \\
55.1 \pm 1.45\end{array}$ & $\begin{array}{l}(51.5-57.1)^{*} \\
52.9 \pm 2.39\end{array}$ \\
\hline $\begin{array}{l}\text { Alkalinity } \\
\text { (mg/l) }\end{array}$ & 200 & $\begin{array}{l}(67-75)^{*} \\
69.6 \pm 3.21\end{array}$ & $\begin{array}{l}(70-76)^{*} \\
74.6 \pm 2.61\end{array}$ & $\begin{array}{l}(73-78)^{*} \\
74.8 \pm 1.92\end{array}$ & $\begin{array}{l}(74-89)^{*} \\
83.2 \pm 5.93\end{array}$ \\
\hline $\begin{array}{l}\text { Chloride } \\
(\mathrm{mg} / \mathrm{l})\end{array}$ & 250 & $\begin{array}{l}(43-71)^{*} \\
61.2 \pm 11.71\end{array}$ & $\begin{array}{l}(55-75)^{*} \\
68.2 \pm 7.85\end{array}$ & $\begin{array}{l}(62-70)^{*} \\
66.6 \pm 3.21\end{array}$ & $\begin{array}{l}(71-78)^{*} \\
74.8 \pm 2.86\end{array}$ \\
\hline $\begin{array}{l}\text { DO } \\
(\mathrm{mg} / \mathrm{l})\end{array}$ & $>2$ & $\begin{array}{l}(1.8-3.5)^{*} \\
2.5 \pm 0.70\end{array}$ & $\begin{array}{l}(1.4-2.3)^{*} \\
1.8 \pm 0.38\end{array}$ & $\begin{array}{l}(2.3-3.2)^{*} \\
2.7 \pm 0.41\end{array}$ & $\begin{array}{l}(1.9-3.1)^{*} \\
2.6 \pm 0.53\end{array}$ \\
\hline $\begin{array}{l}\text { BOD } \\
(\mathrm{mg} / \mathrm{l})\end{array}$ & $<1$ & $\begin{array}{l}(0.2-1.2)^{*} \\
0.7 \pm 0.41\end{array}$ & $\begin{array}{l}(0.5-1.3)^{*} \\
0.9 \pm 0.36\end{array}$ & $\begin{array}{l}(0.2-1.2)^{*} \\
0.7 \pm 0.42\end{array}$ & $\begin{array}{l}(\mathrm{ND}-0.9)^{*} \\
0.5 \pm 0.35\end{array}$ \\
\hline $\begin{array}{l}\text { Fluoride } \\
(\mathrm{mg} / \mathrm{l})\end{array}$ & 1.5 & $\begin{array}{l}(4.7-5.1)^{*} \\
4.8 \pm 0.23\end{array}$ & $\begin{array}{l}(4.6-5.3)^{*} \\
4.9 \pm 0.25\end{array}$ & $\begin{array}{l}(5.1-5.8)^{*} \\
5.4 \pm 0.34\end{array}$ & $\begin{array}{l}(4.6-4.9)^{*} \\
4.8 \pm 0.12 \\
\end{array}$ \\
\hline
\end{tabular}

*= Range 
Moderate positive correlation of $\mathrm{pH}$ was observed with alkalinity $(+0.41)$ and chloride $(+0.45)$. Results of EC were in accordance with Samal et al. (2020).Total Dissolved Solids (TDS) is mainly due to the presence of ions/salts in water (Tyagi et al., 2020). TDS was found minimum at site 3 (475.0mg/l \pm 13.49$)$ and maximum was found at site $4(507.8 \mathrm{mg} / 1 \pm 9.09)$. TDS was found below the standard limit of BIS $(500 \mathrm{mg} / \mathrm{l})$ except at site land 3 but at all the sites TDS was increasing and will be above the standard limit of BIS $(500 \mathrm{mg} / \mathrm{l})$ very soon. Turbidity is an aesthetic parameter with enduring health effect (Hejaz et al., 2020). Turbidity was found minimum at site 2 and 4 $(2.2 \mathrm{NTU} \pm 0.34)$ and maximum was found at site 1 (3.6NTU \pm 0.60$)$. A very strong positive correlation of turbidity was observed with magnesium $(+0.95)$ while strong negative correlation with alkalinity ($0.78)$ and chloride (-0.88). No correlation was observed between turbidity and BOD. Turbidity was found below the standard limit of BIS (5NTU) at all the sites during the study period. Total Hardness (TH) is a crucial water quality parameter, if the concern is domestic, industrial or agricultural use. TH is caused due to calcium and magnesium salts, chloride and Sulphate (WHO, 2011; Adimalla and Venkatayogi, 2018). The main sources of calcium and magnesium in water are geogenic. $\mathrm{TH}$ was found minimum at site $4(322.4 \mathrm{mg} / 1 \pm 5.98)$ and maximum was found at site 1 and 3 (346.6mg/l \pm 7.99$)$. A very strong positive correlation of $\mathrm{TH}$ was observed with magnesium $(+0.78)$ and calcium $(+0.84)$ while very strong negative correlation with alkalinity $(-0.92)$ and chloride $(-0.92)$ and moderate positive correlation was observed with BOD $(+0.55)$ and fluoride $(+0.47)$. TH was found above the standard limit of BIS (300mg/l) at all the sites during the study period. Calcium was found minimum at site 4 $(105.8 \mathrm{mg} / \mathrm{l} \pm 6.46)$ and maximum was found at site 2 (122.6mg/l \pm 8.56$)$. Calcium was found above the standard limit of BIS $(70 \mathrm{mg} / \mathrm{l})$ at all the sites during the study period. Magnesium was found minimum at $2(52.5 \mathrm{mg} / \mathrm{l} \pm 4.19)$ and maximum was found at site $1(55.7 \mathrm{mg} / \mathrm{l} \pm 2.41)$. Magnesium was found above the standard limit of BIS (30mg/l) at all the sites during the study period. A very strong positive correlation of $\mathrm{Ca}$ was observed with BOD $(+0.91)$ and calcium $(+0.84)$. Alkalinity was found minimum at site $1(69.6 \mathrm{mg} / \mathrm{l} \pm 3.21)$ and maximum was found at site $4(83.2 \mathrm{mg} / \mathrm{l} \pm 5.93)$. Alkalinity was found below the standard limit of BIS (200mg/l) at all the sites during the study period. Chloride is essential for autotrophic photophosphorylation reactions. High content of chloride in a water body indicates the contamination due to large quantity of sewage inputs. Chloride was found minimum at site $1(61.2 \mathrm{mg} / \mathrm{l} \pm 11.71)$ and maximum was found at site $4(74.8 \mathrm{mg} / \mathrm{l} \pm 2.86)$. Chloride was found below the standard limit of BIS $(250 \mathrm{mg} / \mathrm{l})$ at all the sites during the study period. Dissolved Oxygen (DO) is the amount of oxygen dissolved in water which the aquatic organism uses for their breathing activity. DO was found minimum at site $2(1.8 \mathrm{mg} / 1 \pm 0.38)$ and maximum was found at site $3(2.7 \mathrm{mg} / 1 \pm 0.41)$. Strong negative correlation of DO was with observed with BOD (-0.84). Biochemical Oxygen Demand (BOD) is the amount of oxygen required by bacterial community available in water sample in a fixed period of time for the oxidation of organic and inorganic matter (Bhutiani et al., 2021). BOD was found minimum at site 4 $(0.5 \mathrm{mg} / 1 \pm 0.35)$ and maximum was found at site 2 $(0.9 \mathrm{mg} / 1 \pm 0.36)$. BOD was found below the standard limit of BIS $(<1 \mathrm{mg} / \mathrm{l})$ at all the sites during the study period. Moderate negative correlation of BOD was with observed with alkalinity $(-0.62)$ and chloride $(-0.48)$. The low values of BOD indicate that groundwater is free from organic pollution. Physical parameters like EC and $\mathrm{pH}$ are the possible source of fluoride delineation. Fluoride was found minimum at site 1 and $4(4.8 \mathrm{mg} / 1 \pm 0.12)$ and maximum was found at site $3(5.4 \mathrm{mg} / \mathrm{l} \pm 0.34)$. Fluoride was found above the standard permissible limit of BIS $(1.5 \mathrm{mg} / \mathrm{l})$ at all the sites during the study period. Results were in accordance to Gouri and Choudhary (2017) and Yasmin et al. (2013). Disintegration of fluorite mineral from the parent rocks is favoured by alkaline range of $\mathrm{pH}$ (between 7.6 and 8.6) (Saxena and Ahmed, 2001). In our study, $\mathrm{pH}$ was found in neutral to alkaline range causing dissolution of fluorite mineral causing of high concentration of fluoride in the study area.

\section{Water quality index (WQI)}

Sub index of each parameter and WQI of each site is given in the table 3 . The results based on the weighted arithmetic water quality index (WQI) calculated by using the selected parameters such as 
Table 3: Showing correlation coefficient between the different physicochemical parameters

\begin{tabular}{|l|l|l|l|l|l|l|l|l|l|l|l|l|l|}
\hline & Temp & $\mathbf{p H}$ & TDS & EC & Turb & TH & Ca & Mg & DO & BOD & Alk & CI & F \\
\hline Temp & 1.00 & & & & & & & & & & & & \\
\hline pH & 0.47 & 1.00 & & & & & & & & & & \\
\hline TDS & -0.56 & -0.59 & 1.00 & & & & & & & & & \\
\hline EC & -0.56 & -0.59 & 1.00 & 1.00 & & & & & & & & & \\
\hline Turb & 0.94 & 0.16 & -0.44 & -0.44 & 1.00 & & & & & & & & \\
\hline TH & 0.92 & 0.76 & -0.75 & -0.75 & 0.75 & 1.00 & & & & & & & \\
\hline Ca & 0.61 & 0.98 & -0.55 & -0.55 & 0.32 & 0.84 & 1.00 & & & & & & \\
\hline Mg & 0.90 & 0.19 & -0.66 & -0.66 & 0.95 & 0.78 & 0.30 & 1.00 & & & & & \\
\hline DO & 0.10 & -0.53 & -0.36 & -0.36 & 0.34 & -0.05 & -0.54 & 0.53 & 1.00 & & & & \\
\hline BOD & 0.32 & 0.90 & -0.18 & -0.18 & 0.00 & 0.55 & 0.91 & -0.09 & -0.84 & 1.00 & & & \\
\hline Alk & -0.93 & -0.67 & 0.41 & 0.41 & -0.78 & -0.92 & -0.80 & -0.67 & 0.27 & -0.62 & 1.00 & & \\
\hline Cl & -0.98 & -0.56 & 0.45 & 0.45 & -0.88 & -0.92 & -0.71 & -0.78 & 0.11 & -0.48 & 0.99 & 1.00 & \\
\hline F & 0.19 & 0.54 & -0.92 & -0.92 & 0.06 & 0.47 & 0.43 & 0.33 & 0.31 & 0.14 & -0.09 & -0.10 & 1.0 \\
\hline
\end{tabular}

Table 4: Showing average observed value (OV), sub index and WQI value at all the four study sites.

\begin{tabular}{|c|c|c|c|c|c|c|c|c|}
\hline \multirow{2}{*}{ Parameters } & \multicolumn{2}{|l|}{ Site-1 } & \multicolumn{2}{|c|}{ Site-2 } & \multicolumn{2}{|c|}{ Site-3 } & \multicolumn{2}{|l|}{ Site-4 } \\
\hline & OV & $\mathbf{S i}$ & OV & $\mathbf{S i}$ & OV & $\mathbf{S i}$ & OV & $\mathbf{S i}$ \\
\hline pH & 7.4 & 48.63 & 7.5 & 60.78 & 7.5 & 58.35 & 7.3 & 31.61 \\
\hline TDS & 496.2 & 0.90 & 501.4 & 0.91 & 475.0 & 0.87 & 507.8 & 0.93 \\
\hline EC & 751.8 & 1.37 & 759.7 & 1.39 & 719.7 & 1.31 & 769.4 & 1.40 \\
\hline TH & 346.6 & 1.76 & 337.8 & 1.71 & 346.6 & 1.76 & 322.4 & 1.63 \\
\hline Calcium & 118.4 & 9.60 & 122.6 & 9.94 & 120.6 & 9.77 & 105.8 & 8.57 \\
\hline Magnesium & 55.7 & 28.20 & 52.5 & 26.60 & 55.1 & 27.93 & 52.9 & 26.77 \\
\hline DO & 2.5 & 5.33 & 1.8 & 3.99 & 2.7 & 5.81 & 2.6 & 5.72 \\
\hline Alkalinity & 69.6 & 0.79 & 74.6 & 0.85 & 74.8 & 0.85 & 83.2 & 0.95 \\
\hline Chloride & 61.2 & 0.45 & 68.2 & 0.50 & 66.6 & 0.49 & 74.8 & 0.55 \\
\hline Fluoride & 4.8 & 968.45 & 4.9 & 992.76 & 5.4 & 1090.01 & 4.8 & 972.50 \\
\hline WQI including Fluoride & \multicolumn{2}{|l|}{250.79} & \multicolumn{2}{|c|}{258.78} & \multicolumn{2}{|c|}{281.78} & \multicolumn{2}{|c|}{247.30} \\
\hline WQI excluding Fluoride & \multicolumn{2}{|l|}{80.23} & \multicolumn{2}{|l|}{88.19} & \multicolumn{2}{|l|}{88.59} & \multicolumn{2}{|l|}{64.60} \\
\hline
\end{tabular}

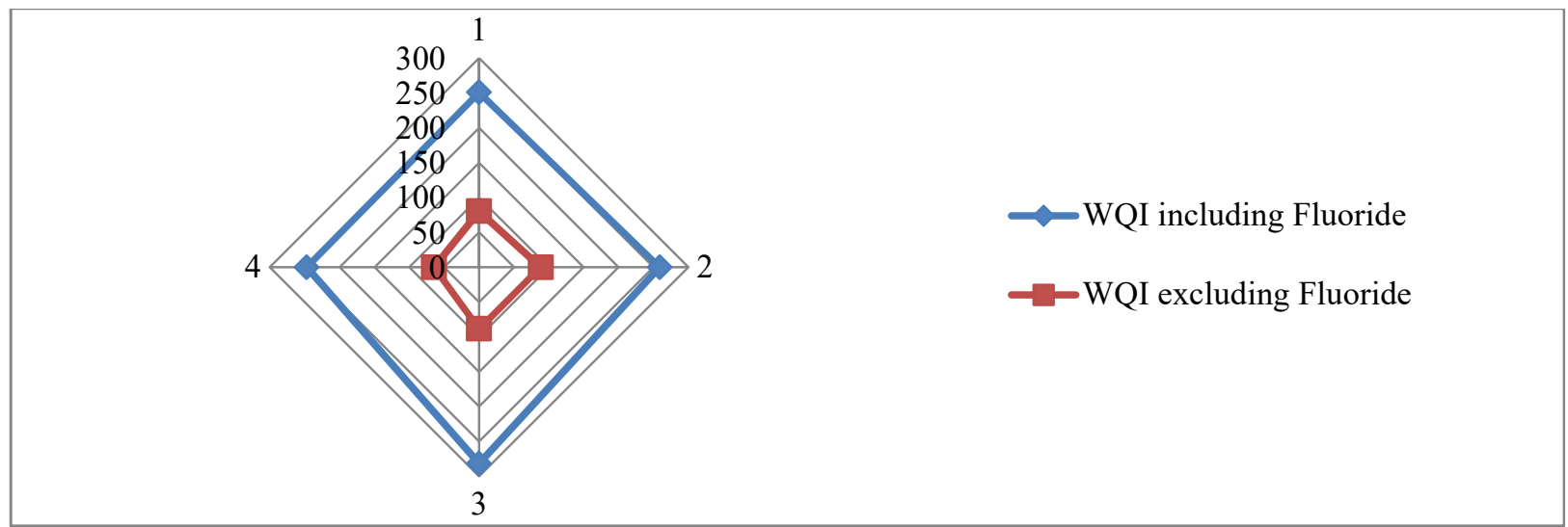

Figure 2: Showing the values of WQI at all the four study sites

$\mathrm{pH}, \mathrm{TDS}, \mathrm{EC}, \mathrm{TH}, \mathrm{Ca}, \mathrm{Mg}, \mathrm{DO}$, alkalinity, quality is unfit for drinking purpose and 80.23 chloride, and fluoride and taking Standard values of excluding fluoride indicates the very poor water BIS (2012) as reference values and taking fluoride as criteria pollutant at each site because of its highest sub index value at all the sites and the least concerning parameter was TDS due to low sub index value. The WQI values of the sites SS-1 was found 250.79 including fluoride indicates that water quality in the area. Similar pattern was found at SS-2 (WQI-258.78, 88.19) and SS-3 (WQI-281.78, 88.59) while at SS-4 WQI values was found 247.30 including fluoride indicates that water quality is unfit for drinking purpose and 64.60 excluding fluoride indicates the poor water quality in the area. 
WQI values in Bokaro district of Jharkhand was observed as 59.39 to 228.16 (poor to unfit for drinking) by Verma et al. (2020). Similar results (WQI-41.64 to 113.69) were also observed by Chaurasia et al. (2018) in different parts of Varanasi. Adimallaa and Qian (2019) also found $95 \%$ of the total ground water samples in unfit for drinking quality.

\section{Conclusion}

The present study was carried out to assess the groundwater quality using water quality index (WQI) based on physicochemical properties in two villages of Rajauli subdivision of district Nawada, Bihar. During the study period, values of total hardness $\quad(322.4 \mathrm{mg} / 1$ to $346.6 \mathrm{mg} / 1)$, calcium $(105.8 \mathrm{mg} / 1$ to $122.6 \mathrm{mg} / \mathrm{l})$, magnesium $(52.5 \mathrm{mg} / 1$ to

\section{References}

Adimalla, N., \& Venkatayogi, S. (2018). Geochemical characterization and evaluation of groundwater suitability for domestic and agricultural utility in semi-arid region of Basara, Telangana State, South India. Applied water science, $8(1), 1-14$.

Aguado, D., Montoya, T., Ferrer, J., \& Seco, A. (2006). Relating ions concentration variations to conductivity variations in a sequencing batch reactor operated for enhanced biological phosphorus removal. Environmental Modelling \& Software, 21(6), 845-851.

Ahmed, I., Tariq, N., \& Al Muhery, A. (2019). Hydrochemical characterization of groundwater to align with sustainable development goals in the Emirate of Dubai, UAE. Environmental Earth Sciences, 78(1), 44.

APHA (2012). In: standards methods for the examination of the water and waste water. American Public Health Association, $22^{\text {nd }}$ Edition, New York.

Bårdsen, A., Bjorvatn, K., \& Selvig, K. A. (1996). Variability in fluoride content of subsurface water reservoirs. Acta Odontologica Scandinavica, 54(6), 343-347.

Bhutiani, R., Ahamad, F., \& Ruhela, M. (2021). Effect of composition and depth of filter-bed on the efficiency of Sand-intermittent-filter treating the Industrial wastewater at Haridwar, India. Journal of Applied and Natural Science, 13(1), 88-94.

Bhutiani, R., Ahamad, F., Tyagi, V., \& Ram, K. (2018). Evaluation of water quality of River Malin using water quality index (WQI) at Najibabad, Bijnor (UP) India. Environment Conservation Journal, 19(1\&2), 191201.
$55.7 \mathrm{mg} / \mathrm{l})$ and fluoride (4.8 to $5.4 \mathrm{mg} / \mathrm{l})$ were found above the standard limit of BIS at all the sites. Fluoride was detected more than 3 times than the standard permissible limit of BIS $(1.5 \mathrm{mg} / \mathrm{l})$. Values of TDS $(496.2 \mathrm{mg} / 1$ to $507.8 \mathrm{mg} / \mathrm{l})$ were found very close to standard BIS limit $(500 \mathrm{mg} / 1)$. Based on WQI including fluoride, water quality falls in unfit for drinking category at all the stud sites while in very poor category at site 1,2 and 3 and poor category at site on the basis of WQI excluding the fluoride. Therefore we can say that fluoride is the criteria pollutant to be considered while designing the treatment facility and health related policies. The study also affirms the great need of water treatment facilities and maintenance of existing treatment \{installed fluoride removal centre (FRC) \} plant in the study area.

Brindha, K., \& Elango, L. (2011). Fluoride in groundwater: causes, implications and mitigation measures. Fluoride properties, applications and environmental management, 1, 111-136.

Brown, R. M., McClelland, N. I., Deininger, R. A., \& Tozer, R. G. (1970). A water quality index-do we dare. Water and sewage works, 117(10).

Bureau of Indian Standards (1992). Indian Standard Specifications for Drinking Water. IS: 10500.

Bureau of Indian Standards (2012). Drinking WaterSpecification, IS 10500:2012, Second Revision, Government of India, New Delhi.

Central Ground Water Board (2013). Ground Water Information Booklet Nawada District, Bihar State.

Chen, Y., Zhang, Y., He, J., Zhang, J., Lang, Q., Liu, H., \& $\mathrm{Wu}, \mathrm{C}$. (2021). Assessment of Groundwater Quality and Pollution in the Songnen Plain of Jilin Province, Northeast China. Water, 13(17), 2414.

Cude, C. G. (2001). Oregon water quality index a tool for evaluating water quality management effectiveness 1. JAWRA Journal of the American Water Resources Association, 37(1), 125-137.

Edmunds, W. M. and Smedley, P. L. 2005. Fluoride in natural waters. In: Selinus, O. (Ed.), Essentials of Medical Geology. Elsevier Academic Press, London, pp. 301-329.

Gouri, K., \& Choudhary, S. K. (2017). Fluoride Contamination in Groundwater Sources of Bhagalpur Municipal Corporation Area, Bhagalpur, Bihar. IOSR Jour. Environ. 

Sci., Toxicology and $\quad$ Food
(IOSRJESTFT), $11(1), 45-49$.

Gupta, S. K., Deshpande, R. D., Agarwal, M., \& Raval, B. R. (2005). Origin of high fluoride in groundwater in the North Gujarat-Cambay region,

Journal, 13(4), 596-605.

Hejaz, B., Al-Khatib, I. A., \& Mahmoud, N. (2020). Domestic Groundwater Quality in the Northern Governorates of the West Bank, Palestine. Journal of environmental and public health, 2020.

Hua, K., Xiao, J., Li, S., \& Li, Z. (2020). Analysis of hydrochemical characteristics and their controlling factors in the Fen River of China. Sustainable Cities and Society, 52, 101827.

Khanna, D. R., \& Bhutiani, R. (2008). Laboratory manual of water and wastewater analysis. Delhi: Daya Publishing House.

Kim, K., \& Jeong, G. Y. (2005). Factors influencing natural occurrence of fluoride-rich groundwaters: a case study in the southeastern part of the Korean Peninsula. Chemosphere, 58(10), 1399-1408.

Kumar, A., \& Kumar, V. (2015). Fluoride contamination in drinking water and its impact on human health of Kishanganj, Bihar, India. Research Journal of Chemical Sciences, 5(2), 76-84.

Kundu, N., Panigrahi, M., Tripathy, S., Munshi, S., Powell, M., \& Hart, B. (2001). Geochemical appraisal of fluoride contamination of groundwater in the Nayagarh District of Orissa, India. Environmental Geology, 41(3-4), 451-460.

Li, Y., Li, P., Cui, X., \& He, S. (2021). Groundwater quality, health risk, and major influencing factors in the lower Beiluo River watershed of northwest China. Human and Ecological Risk Assessment: An International Journal, 27(7), 1987-2013.

Ram, H. K., Ramachandra, M. M., \& Vishalakshi, Y. (2007). Limnological Studies on Kolaramma Lake Kolar, Karnataka. Environment and Ecology, 25(2), 364-367.

Salunke, K. A., Bhave, P. P., \& Mata, M. M. (2014). Performance status of common effluent treatment plant at Dombivati CETP. Int J Res Eng Technol, 3(9), 48-52.

Samal, A. K., Mishra, P. K., \& Biswas, A. (2020). Assessment of origin and distribution of fluoride contamination in groundwater using an isotopic signature from a part of the Indo-Gangetic Plain (IGP), India. HydroResearch, 3, 7584.

Saxena, V., \& Ahmed, S. (2001). Dissolution of fluoride in groundwater: a water-rock interaction study. Environmental geology, 40(9), 1084-1087.
Singh, R. K., \& Singha, M. M. (2009). Fluoride contamination in water of Koshi region (Bihar). International Journal of Chemical Sciences, 7(2), 919-922.

Smedley, P. L., Nicolli, H. B., Macdonald, D. M. J., Barros, A. J., \& Tullio, J. O. (2002). Hydrogeochemistry of arsenic and other inorganic constituents in groundwaters from $\mathrm{La}$ Pampa, Argentina. Applied geochemistry, 17(3), 259-284.

Todd, D. K. (1980). Ground-water Hydrology. Second edition. John Wiley and Sons, New York, p. 535.

Tyagi, S., Dubey, R. C., Bhutiani, R., \& Ahamad, F. (2020). Multivariate Statistical analysis of river ganga water at Rishikesh and Haridwar, India. Analytical Chemistry Letters, 10(2), 195-213.

Vaiphei, S. P., Kurakalva, R. M., \& Sahadevan, D. K. (2020). Water quality index and GIS-based technique for assessment of groundwater quality in Wanaparthy watershed, Telangana, India. Environmental Science and Pollution Research, 27(36), 45041-45062.

Verma, D. K., Bhunia, G. S., Shit, P. K., \& Tiwari, A. K. (2018). Assessment of groundwater quality of the Central Gangetic Plain Area of India using Geospatial and WQI Techniques. Journal of the Geological Society of India, 92(6), 743-752.

Vithanage, M., \& Bhattacharya, P. (2015). Fluoride in the environment: sources, distribution and defluoridation. Environmental Chemistry Letters, 13(2), 131-147.

WHO (2004). International Standards for Drinking Water. World Health Organization, Geneva, pp. 55-79.

WHO (2011). World Health Organisation Guidelines for Drinking Water Quality, 4rd ed. Incorporating the First and Second Addenda, vol. 1 Recommendation, Geneva.

Yasmin, S., Ranjan, S., Hilaluddin, \& D'Souza, D. (2013). Effect of excess fluoride ingestion on human thyroid function in Gaya region, Bihar, India. Toxicological \& Environmental Chemistry, 95(7), 1235-1243.

Yousefi, M., Ghoochani, M., \& Mahvi, A. H. (2018). Health risk assessment to fluoride in drinking water of rural residents living in the Poldasht city, Northwest of Iran. Ecotoxicology and environmental safety, 148, 426430.

Yuan, Y., Liu, Y., Luo, K., \& Shahid, M. Z. (2020). Hydrochemical characteristics and a health risk assessment of the use of river water and groundwater as drinking sources in a rural area in Jiangjin District, China. Environmental Earth Sciences, 79(7), 1-15. 